\title{
The Kids Are Alright -- Or, Are They?: The Millennial Generation's Technology Use and Intelligence -- an Assessment of the Literature
}

\author{
Jennifer Horwath \\ eLibrarian \\ Mohawk College of Applied Arts and Technology \\ Hamilton, Ontario \\ Cynthia Williamson \\ Collection Management Librarian \\ Mohawk College of Applied Arts and Technology \\ Hamilton, Ontario
}

\section{Introduction}

Much has been written about the prowess of the Millennial generation. These "digital natives" have been attributed with the ability to process information, make decisions, multi-task, and learn new technologies better than any generation that has come before. In addition, some authors and speakers in the field of librarianship and education have described this group of people as being of significantly higher intelligence than people born in previous generations. Furthermore, many commentators have noted that this generation, having grown up surrounded by technology, uses Web 2.0 tools with much greater ease and frequency than their older counterparts. They have stressed that in order to reach this generation, academic libraries must use Web 2.0 technologies such as blogs, podcasts, wikis, webpage commenting, instant messaging, and spaces in Second Life.

After defining what is meant by the term "Millennials", this paper attempts to identify the myths and discover the reality about this generation. Descriptions of this generation that have often been repeated in the literature are compared to quantitative and qualitative studies of their technological skills and intelligence and their use of Web 2.0 technologies. The paper concludes by discussing the implications of the authors' findings for service delivery in academic libraries and provides recommendations for libraries and educational institutions that serve this generation.

\section{The Millennial Generation Defined}

For the purposes of this paper, we are using the birth years 1979 -1988 to refer to Millennials. This age cohort is also known as the 'Net Generation' or Generation $Y$. Dates used in the literature to define Millennials have ranged from 1979 to 1982 (Howe 42; Sweeney 165). Generally, we regard Millennials as students who are currently aged 18-24 and who are in first or second year of 
college or university; those who form a large part of our user base in academic libraries.

Many of our perceptions of the Millennial generation have been shaped by the writings of scholars in the fields of librarianship and education. Marc Prensky first coined the term "digital native" in his article "Digital Natives, Digital Immigrants" in 2001. An author, educator, game developer and speaker in the fields of gaming and education, Prensky's writings on this generation have become the accepted wisdom about Millennials for many librarians and educators. The main tenets of his ideas are that Millennials think and process information differently from their predecessors, that their brains have physically changed, and that they parallel process and multi-task unlike people of previous generations. Prensky postulates notes that these changes have taken place because Millennials, the digital natives, have been using computers for most of their lives, unlike older people, the digital immigrants, who started using computers later in life. These ideas, as evidenced by widespread use of the "digital natives" terminology, are often quoted in library and education literature (Abram 2007; Oblinger 2005; Sweeney 2005; Tapscott 2008).

In addition to making assertions about the unique brains of the Millennials, authors in library literature have also noted that this generation is more intelligent than preceding generations. Abram asserts that "there is a growing body of research that their IQ's, their raw ability to access and use their intelligence has grown markedly and at a level of statistical significance" (57). As well, Sweeney states that "There are research findings showing that Millennials get higher scores on both SAT exams and standard IQ tests" (169) while Tapscott notes that they may be the "smartest generation ever" (30).

Prensky and others also believe that the technical abilities of Millennials are remarkable. Prensky notes that it is possible that "kids" could build their own computers to be used at school and that "all 21st century kids are programmers to some degree" ("Listen" 12). Similarly, Oblinger notes that "Having grown up with widespread access to technology, the Net Gen is able to intuitively use a variety of IT devices and navigate the Internet" (2.5). These authors surmise that because the Millennial students possess advanced technological abilities it follows that they are avid users of the latest Web 2.0 technologies such as blogs, podcasts, online video games, instant messaging, virtual worlds such as Second Life, and social networks such as Facebook and Myspace. They describe students who are Web 2.0 content creators not merely content consumers. Prensky for example, notes that:

Our young people ....[are] busy adopting new systems for communication (instant messaging), sharing (blogs), buying and selling (eBay), exchanging (peer-to-peer technology) creating (Flash), meeting (3D worlds), collecting (downloads), coordinating (wikis), evaluating (reputation systems), 
searching (Google), analyzing (SETI), reporting (camera phones), programming (midding), socializing (chat rooms), and even learning (Web surfing). ("Listen" 10)

In sum, the picture that emerges is of a Millennial student who is technologically savvy, highly intelligent, and intensely interested in using the latest Web 2.0 tools to create online content. We will examine each of these characteristics in turn.

\section{The Technological Proficiency of the Millennial}

To test the ideas of Prensky et al, we looked at various quantitative studies that measured the technological proficiencies of the Millennial and of college and university students in general. One such study is the ECAR (EDUCAUSE Center for Applied Research) study. The ECAR study of Undergraduate Students and Technology has been undertaken every year since 2004 with slight variations in the questions and number of participants each year. Each study takes place in the spring and is released in the fall; the most recent study (2008), comprised a survey of 27,317 students from 90 four-year institutions and 8 two-year institutions in the U.S. as well as focus groups.

The study found most respondents to be "wired with technology"; they claimed to own laptops, use email and instant messaging, and play videogames. Unlike studies from previous years, the 2008 study found that Net Gen students are actively using IT tools to communicate and taking advantage of Web 2.0 technologies to express themselves. A close look at the data however, reveals that these students are not overwhelmingly embracing technologies or are mainly using these tools for social communication rather than content creation. Many of the study participants responded that they text message daily and use social network sites such as Facebook daily, download web-based music or videos weekly and instant message several times a week. In spite of this frequent and regular use of information technology tools, when it comes to the use of complex software or content creation using Web 2.0 tools, there is less usage: only $32.9 \%$ use video creation software once per quarter/semester, $34.1 \%$ contribute to blogs monthly, $29.4 \%$ play online multiuser computer games monthly, $8.8 \%$ visit Second Life monthly and $16.7 \%$ use social bookmarking sites monthly (4).

The FIT (Fluent in Technology) survey, undertaken at Southwestern University in Texas, revealed similar findings. This survey was administered in spring, 2001, the same year that Prensky published Digital Natives, Digital Immigrants, and sought to discover students' ratings of their own fluency with information technology through its 300 responses and twenty interviews. Researchers found that skill levels were highest in the use of word processing, browsing the Internet and email. Skill levels were lower for specialized applications such as spreadsheets and presentation software. High percentages of students had never created webpages or worked with graphics (58\% and $61.3 \%$ respectively). 
Likewise, the ECAR 2006 study reported a majority of respondents falling into minimal or no use categories for webpage, audio and video creation software. The authors of the FIT study noted that the assumption is made that students come to college with high level skills such as working with spreadsheets and databases, creating webpages, etc. However, if studies such as these are taken into account, administrators and faculty need to realize that students may require training opportunities in these areas after they enter college (McEuen 16). An analysis of the "digital natives" debate published in 2008 takes a similar view. In this paper, the authors note that there is some limited research evidence that shows that young people are highly adept with technology and use it for information and communication, however "there also appears to be a significant proportion of young people who do not have the levels of access or technology skills predicted by proponents of the digital native idea" (Bennett, Maton and Kervin 778-9).

Likewise, a study commissioned by The British Library and JISC, while not a study of Millennials but of even younger students, lends credence to the idea that younger people are not naturally technologically adept. In addition, this study probes the technology use of young people at a deeper level and analyzes their actual proficiency and skill level with online tools; in other words, their information literacy. The focus of The British Library study was the technological fluency of students born post-1993, a group they called "the Google generation". Researchers completed literature studies as well as an analysis of the information seeking behaviour of school children as compared to adults when searching two particular online databases (BL Learn and Intute). They concluded that the "information literacy of young people has not improved with the widening access to technology: in fact, their apparent facility with computers disguises some worrying problems" (University College London 12).

Indeed, many of the problems cited relate to information literacy; young people do not understand how information retrieval systems work or how content on the Internet is organized and so cannot formulate effective searches (University College London 22). Young people also do not attempt to evaluate information for relevance, accuracy or authority. Similar findings are evident in the OCLC report College Students' Perceptions of Libraries and Information Resources, published in 2006. The OCLC report found that in addition college students do not have a mental map of how content is organized on the Internet. The report notes that "Many college students do not differentiate between what is offered by libraries and what is offered by search engine companies" (OCLC 6-4). The British Library report notes that a picture emerges from the research of "a large minority of freshmen entering college and university with low levels of information literacy and high levels of library anxiety" (University College London 23). In addition, this study declares that much writing on the topic of the technology skills of young people "overestimates the impact of ICTs (Information Communication Technology) on the young and underestimates its effect on older generations" (University College London 21). The researchers quote studies that find that there 
is no significant difference between the information seeking behaviour of young students and that of early middle-aged students and faculty. To conclude, our survey of the literature finds that the technological proficiency of the Millennial does not seem to be at an advanced level. More importantly, there appear to be disturbing concerns around the information literacy levels of young people.

\section{The Intelligence of the Millennial}

While there is much controversy surrounding the use of IQ scores as a measure of intelligence, our purpose was to discover if there is support for the premise that the Millennial generation is "the smartest generation ever" (Tapscott 30) whose IQ scores have risen "at a level of statistical significance" (Abram 57). We found evidence that the IQ of the Millennial student is greater than that of preceding generations in studies that indicate that IQ scores have been rising every decade since the last century. However we could find no evidence that the increase in IQ scores is any greater for the Millennial generation than for preceding generations or that an increase in intelligence scores is a unique phenomenon of this generation.

The increase in IQ scores from generation to generation is called "the Flynn Effect", named for a phenomenon discovered by psychologist James Flynn. He noted that IQ scores have increased by 3-5 points per decade in the last century and that "gains in the neighbourhood of 18-20 IQ points in a generation seem to be quite typical in many industrialized countries" (qtd. in Sundet, Barlaug, and Torjussen 350). This phenomenon is therefore not unique to the Millennial generation. In fact, there is evidence of decreases in IQ scores within the Millennial generation; studies in Norway and Denmark have found declining scores for 18-19 year olds tested in 2004 (Teasdale and Owen 842).

Furthermore, a complete cessation of IQ gains between the mid 1990s and 2002 has been noted in Norway (Sundet, Barlaug and Torjussen 355).

We also investigated Prensky's claim that "it is very likely that our students' brains have physically changed - and are different from ours" (1) and Abram's assertion that "MRI studies of their brains show that they use a greater degree... of their brains and have greater physical capacity through increased ganglia and folds of their brains" (58). Research does show, and it is now widely accepted, that learning tasks results in physical changes in the brain. Studies on taxi drivers and musicians, for example, have shown that the brain physically changes when learning takes place (Maguire et al. 4399; Gaser and Schlaug 9240). As well, there are studies that show that playing videogames or engaging with technology in other ways, stimulates the brain or increases brain activity (Fritz, 1; Johnson, 1). So, while we do not unequivocally dispute Prensky's and Abram's claims, the significance of this change to the brain of the Millennial is unclear. We could find no evidence in the literature to support the idea that there is a direct relationship between a change in the structure or folds of the brain and intelligence. Research is still ongoing in this area. As one researcher has noted, 
"It is interesting to note that so much ongoing research is invested in seeking to associate gross physical brain structures with intellectual abilities when there exists little solid evidence to bolster such connections" (Herskovits 196). Nor could we find any support for the notion that physical changes in the brain due to learning is a phenomenon unique to the Millennial generation. We conclude therefore that the suppositions made by Abram, Tapscott and Prensky regarding the increased IQ scores or brain development of the Millennial generation do not contribute meaningfully to an understanding of the true skills, intelligence or abilities of this generation.

\section{The Adoption of Web 2.0 Tools by the Millennial}

Books such as Social Software in Libraries, Library 2.0: A Guide to Participatory Library Service, Web 2.0 and Libraries, Part 2: Trends and Technologies and How to Use Web 2.0 in Your Library as well a many similar titles have appeared in the library literature over the past few years. These books encourage librarians to use Web 2.0 tools to better engage our student users who are supposedly avid users of these technologies. And yet, several research studies have found that students are not using these tools as much as we expect and older users are now showing an increased adoption of these tools, so that the divide between the digital immigrants and digital natives is closing.

OCLC's report Sharing, Privacy and Trust in a Networked World, published in September of 2007 found that "the participation in many online activities by the college students surveyed outpaced that of the total general public" (De Rosa A2). However, a closer look at the data finds that there isn't a huge difference between the use of social software sites by college students and the general public. Only $27 \%$ of college students surveyed reported that they blogged compared to $17 \%$ of the general public and $59 \%$ of college students reported that they read blogs compared to $45 \%$ of the general public (De Rosa A-2). Similarly, only $27 \%$ of students contributed content to another's webpage while $20 \%$ of the general public reported doing so (De Rosa A-2). The report noted that while it could not conclude definitively that age differences in the use and adoption of Internet tools do not exist, "due to widespread adoption of digital technologies over more than a decade, the behaviours and attitudes of these two technology generations are beginning to converge" (De Rosa 1-1).

Similarly, a June 2009 report from Nielson finds that teens are not unique in their use of media. According to Neilson, "Teens ...spend far less time browsing (the Internet) than adults... watch less online video than most adults and (their) favourite TV shows, top websites and genre preferences across media are mostly the same as most of their parents" (Nielsen 1). Likewise a Pew Internet and American Life project reported in a 2009 study that adults make up the bulk of the users on social network sites and that the number of adult users of these sites has more than quadrupled in the last four years (Lenhart 1). The Pew study includes people aged 18-24 within the definition of "adult"; however the study 
notes that $87 \%$ of online adults aged $25-44$ have a profile on a social network, compared to $75 \%$ of $18-24$ year old adults (Lenhart 1 ).

A 2007 study that investigated access and use of 41 technology-based tools by 2,588 first year students from three Australian universities also reported that Millennials are not unique in their use of Web 2.0 tools. Kennedy et al concluded that "While there was evidence that social networking and digital file sharing was popular among a small minority of students, few students were regularly using social bookmarking or creating and publishing podcasts" (Kennedy et al. 522). They also noted that in regard to Web 2.0 tools, their results "suggest that most students are very infrequent users of these technologies" (Kennedy et al. 520).

Studies conducted by the authors in 2007 and 2009 at Mohawk College also support the idea that Millennials are not unique in their approach to the Internet or Web 2.0 technologies. The participants in our surveys were not randomly selected and no effort was made to create a representative sample of the entire college student population, therefore our results are to be considered as a starting point for further research only. Mohawk College is one of twenty four applied arts and technology colleges in Ontario and features a wide variety of programs. The most popular programs are nursing and medical technologies, skilled trades and manufacturing technologies. About 10,000 postsecondary students attend the college each year. Most of the survey responses came from Mohawk College's largest campus (Fennell), where there is a wide variety of programs in areas ranging from arts to media to engineering to business.

In 2007, 389 students completed the survey and in 2009, 313 students completed the survey. In both surveys over $60 \%$ of respondents were first year students in the Millennial age group (15-24 years old). The goal of both surveys was to determine the level of use of Web 2.0 tools amongst Mohawk College Millennial students. Those who took the survey were presented with a list of thirty-two online activities (such as blogging, photo sharing, social bookmarking, playing online videogames, etc.) and asked to rate them with response choices ranging from "I don't know what this technology is" to "I do this a lot (more than 10 times per week)". They were also asked about their comfort level and desire for training in using online tools in their coursework. The surveys were conducted using the online tool Survey Monkey. In 2007, surveys were printed and handed out during library class visits and made available in the libraries as well as online on the library website and campus portal. In 2009, the survey was only made available online, with links in the campus portal and on the library website. Bookmarks with the survey URL were handed out at all library locations and during library class visits. There was little change in the responses from 2007 to 2009; the following commentary focuses on the results of the 2009 survey.

When asked about blogging, podcasting, creating or contributing to a wiki, and use of Twitter, the majority of Millennial respondents consistently chose "I know what this is but have not tried it". When asked about online gaming, $46.8 \%$ of the 
Millennial students surveyed said they play video games occasionally (defined in the survey as fewer than 5 times per week); and when asked about Massive Multiplayer Online Games such as World of Warcraft, the majority of Millennials $(54.5 \%)$ chose "I know what this is but have not tried it" while only $3.4 \%$ chose "I do this a lot". Meanwhile, $49.5 \%$ of the Millennial student respondents chose "I know what this is but have not tried it" when asked if they have created an avatar in a virtual world such as Second Life. These findings are similar to those of the ECAR study noted above.

Millennial respondents to the surveys claimed to know of but had little use for two of the more practical web 2.0 tools: RSS feeds and social bookmarking. The majority (35.5\%) responded "I know what this is but have not tried it" when asked about their use of RSS feeds. "I do not know what this technology is" and "I know what this is but have not tried it" were chosen by the majority $(75.4 \%$ combined) when asked about their use of social bookmarking tools. The most popular Web 2.0 tools for Millennial respondents were chatting (56.8\% claim to do this "a lot -- more than ten times per week") and Facebook (60\% claim to use it a lot). Again, this echoes the results of the ECAR 2008 study that found that a vast majority of respondents regularly use Facebook above all other Web 2.0 tools.

The survey also attempted to discover Mohawk students' preferences for the use of technology at school and their comfort levels with the tools they are asked to use. When asked how much of their coursework (assignments, exams, quizzes, discussions, communication with instructors, readings, etc.) they preferred online, "all", "most", "some" or "none", just under half of those respondents aged 15-24 years old chose "some" and only 9.4\% chose "all". When asked if they would have preferred to have received training in the use of their Learning Management System, a surprising $36.7 \%$ of the Millennial-aged respondents said "yes". The Learning Management System was defined in the survey "as the online space where your instructor places course materials, quizzes, course discussion boards, etc.". Students were also asked about their preferred method of contacting the library. The Mohawk library offers phone, email and chat reference service, yet $59 \%$ of the Millennial respondents chose "in person" as their preferred way to reach the library when they need help. Our conclusion is that Millennial students are not as interested in using Web 2.0 tools for content creation as they are in using social tools such as chat and Facebook for communication.

\section{Discussion}

The question then arises, what, if anything, can we do with the knowledge that our students are not as engaged with Web 2.0 tools or as technologically savvy as we have been led to believe? With regard to the development of new library services, librarians are returning to a cycle where analysis of user needs comes first, then the creation of services to fill those needs, and lastly, the choice of the 
appropriate tool to deliver the service is made, a positive trend. Librarians should rely on user studies such as surveys and focus groups, and interactions with our students in the library and in the classroom rather than being swayed by popular and oft-repeated notions of the intelligence and technological fluency of the Millennials. Awareness of the diversity of learning styles has existed in education for a very long time now. It is as wrongheaded to assume that all students will learn if they are gaming as it is to assume that everyone can learn from a three hour lecture. A diversity of services and delivery methods for reference, research instruction and outreach as well as an in-depth knowledge of the needs of our users are clearly required.

Furthermore, it is best not to assume that our users know how to do research or that they use more than the basics of most practical software just because they are frequent users of text, chat and social websites like Facebook. Nor can it be assumed that they want to use these technologies to learn just because they use them in their social lives. Indeed, there is a danger in assuming that students are entering college and university equipped with the technological skills they require in order to succeed. Moreover, the popular writers do not discuss students whose first language is not English; nor do we see any discussion or investigation into the technological abilities of those students with special needs. From many different perspectives, culture, language, physical abilities, age and gender to name some, there is wide diversity in our students. Not all will thrive in a high technology educational setting even if some of them might do remarkably well.

Finally, we have found that many of the beliefs about this generation are based on questionable research methods and specious arguments. As organizations whose chief mandate is "to educate", we do a disservice to our students if we design and deliver curriculum and library services based on popular yet unsubstantiated claims. This problematic research has been repeated and quoted so many times and by such respected leaders in our field, that it becomes a kind of commonly held belief that few think to question. Examples of questionable research methods discovered by the authors include use of one's own children as research subjects; misspelling the name of a key source; taking a person's research out of context to support one's own ideas; using focus groups conducted in front of an audience as a research method; conducting a study of how Millennials compare to previous generations at the same age and then including no research into the characteristics of these previous generations; and not including any citations for research findings quoted within a paper. As academic libraries have as part of their mandate the preservation and dissemination of research, we suggest that academic librarians need to be especially critical of research that is intended for use in service and priority development. 


\section{Conclusion}

We find that much that has been written about this generation is unsubstantiated by research and that actual data tells a different story about the Millennial generation. The technological literacy and fluency of Millennials are not as strong as described in the literature by Prensky, Abram and others. Nor does research indicate definitively that the intelligence of Millennials is greater than that of previous generations or that the increase in the IQ scores of this generation over previous generations is a unique phenomenon. As well, it appears that Millennials are not using Web 2.0 tools to a greater extent than people of other age groups. In fact, many researchers have noted that terms such as "digital native" and "digital immigrant" are no longer useful, as the gap between generations and their use of Web 2.0 tools has almost closed. While some young people may be adept at using new technologies, it is dangerous to assume that all young people are exactly the same or that a cookie cutter approach to library service development is acceptable. We recommend that librarians investigate the true nature of their users through focus groups, surveys, usability studies or other methods so that they can develop services that meet actual needs and abilities. We further recommend that librarians question the research behind commonly held beliefs about our users; in this way we promote quality research and evidence-based practice. 


\section{Works Cited}

Abram, Stephen. "Millennials: Deal with Them! Part I." $\underline{\text { School Library Media }}$

Activities Monthly 24.1 (2007): 57-58. Academic Search Premier.

EBSCOhost. Mohawk College Library. 21 July 2009

$<\underline{\text { http://search.ebscohost.com.rap.bibliocentre.ca/ }}$

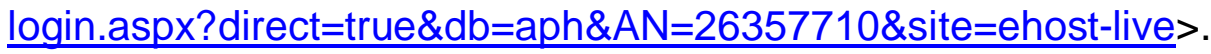

Bennett, Sue, Karl Maton, and Lisa Kervin. "The 'Digital Natives' Debate: A

Critical Review of the Evidence." British Journal of Educational

Technology 39.5 (2008): 775-86. Academic Search Premier. EBSCOhost.

Mohawk College Library. 15 July 2009 <doi:10.1111/j.1467-

8535.2007.00793.x $>$.

De Rosa, Cathy, Joanne Cantrell, Andy Havens, Janet Hawk et al.. Sharing, Privacy and Trust in Our Networked World: A Report to the OCLC Membership. Dublin, OH: OCLC, 2007.

De Rosa, Cathy, Joanne Cantrell, Janet Hawk, and Alane Wilson. $\underline{\text { College }}$

Students' Perceptions of Libraries and Information Resources: A Report to the OCLC Membership. Dublin, OH: OCLC, 2006.

Fritz, Sandy. "Sounding Out Dyslexia." Scientific American Mind 19.2 (Apr. 2008): 12-12. Academic Search Premier. EBSCOhost. Mohawk College Library, Hamilton, Ont. 8 Sep. 2009 $<$ http://ezproxy.mohawkcollege.ca:2053/login.aspx?direct=true\&db=aph\&

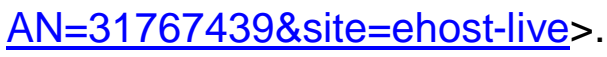


Gaser, Christian, and Gottfried Schlaug. "Brain Structures Differ between Musicians and Non-Musicians." The Journal of Neuroscience 23.27 (2003): 9240-45. 16 July 2009 $<$ http://www.jneurosci.org/cgi/reprint/23/27/9240>.

Herskovits, A. Zara. "A Brief History of Einstein's Brain." Einstein Quarterly: Journal of Biology \& Medicine 17.4 (Oct. 2000): 194. Academic Search Premier. EBSCOhost. Mohawk College Library, Hamilton, Ont. 9 Sep. 2009 <http://ezproxy.mohawkcollege.ca:2053/

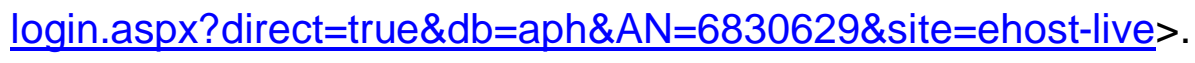

Howe, Neil, and William Strauss. Millennials Rising: The Next Great Generation. New York: Vintage Books, 2000.

Johnson, Steven. "Your Brain on Video Games." Discover 26.7 (July 2005): 3843. Academic Search Premier. EBSCOhost. Mohawk College Library, Hamilton, Ont. 8 Sep. 2009 <http://ezproxy.mohawkcollege.ca:2053/login.aspx?direct=true\&db=aph\& $\underline{\mathrm{AN}=17321031 \& \text { site }=\text { ehost-live }}>$.

Kennedy, Gregor, Barney Dalgarno, Kathleen Gray, Terry Judd et al.. "The Net Generation are not Big Users of Web 2.0 Technologies: Preliminary Findings." Proceedings ascilite Singapore 2007 (2007): 517-25. 12 Apr. $2008<$ http://www.ascilite.org.au/conferences/singapore07/ procs/kennedy.pdf 
Lenhart, Amanda. Adults and Social Network Websites. 14 Jan. 2009. Pew Internet \& American Life Project. 3 Aug. 2009 $<$ http://pewinternet.org/Reports/2009/Adults-and-Social-NetworkWebsites.aspx>.

Maguire, Eleanor A., David G. Gadian, Ingrid S. Johnsrude, Catriona D. Good et al.. "Navigation-related Structural Change in the Hippocampi of Taxi Drivers." Proceedings of the National Academies of Sciences 97.8 (2000): 4398-403. 14 July 2009 $<$ http://www.pnas.org/content/97/8/4398.full >.

McEuen, Sharon F. "How Fluent with Information Technology are Our Students?" EDUCAUSE Quarterly 24.4 (2001): 8-17. 1 Nov. 2008 $<$ http://net.educause.edu/ir/library/pdf/eqm0140.pdf $>$.

The Nielsen Company. How Teens Use Media: A Nielsen Report on the Myths and Realities of Teen Media Trends. Nielsen, 2009. 31 July 2009 $<\underline{\text { http://blog.nielsen.com/nielsenwire/reports/nielsen howteensusemedia }}$ une09.pdf>.

Oblinger, Diana G., and James L. Oblinger. "Is it Age or IT: First Steps Toward Understanding the Net Generation." Educating the Net Generation. Eds. Diana G. Oblinger and James L. Oblinger. New York: EDUCAUSE, 2005. 
2.1-2.20. 9 Feb. 2009 <http://net.educause.edu/ir/library/pdf/pub7101b. $\underline{\mathrm{pdf}}>$.

Prensky, Marc. "Digital Natives, Digital Immigrants." On the Horizon 9.5 (2001):

1-6. 31 July 2009 <http://www.marcprensky.com/writing/Prensky\%20\%20Digital\%20Natives,\%20Digital\%20Immigrants\%20-\%20Part1.pdf>.

Prensky, Marc. "Listen to the Natives." Educational Leadership 63.4 (2005): 8-13. Academic Search Premier. EBSCOhost. Mohawk College Library. 2 June 2009 <http://search.ebscohost.com.rap.bibliocentre.ca/login.aspx? direct=true $\& \mathrm{db}=a p h \& A N=19270008 \&$ site $=$ ehost-live $>$.

Teasdale, Thoma W., and David R. Owen. "A Long-Term Rise and Recent Decline in Intelligence Test Performance: The Flynn Effect in Reverse." Personality and Individual Differences 39 (2005): 837-43. ScienceDirect. Elsevier. McMaster University Library. 16 Dec. 2007 $<$ doi:10.1016/.j.paid.2005.01.029>.

Salaway, Gail, Judith Borreson Caruso, and Mark R. Nelson. The ECAR Study of Undergraduate Students and Information Technology, 2008. ECAR Research Study. Ser. 8. Boulder, CO: EDUCAUSE, 2008. 14 Dec. 2008 $<$ http://net.educause.edu/ir/library/pdf/ers0808/rs/ers0808w.pdf>.

Sundet, Jon M., Dag G. Barlaug, and Tore M. Torjussen. "The End of the Flynn Effect? A Study of Secular Trends in Mean Intelligence Test Scores of Norwegian Conscripts During Half a Century." Intelligence 32 (2004): 349- 
62. ScienceDirect. Elsevier. McMaster University Library. 16 Dec. 2007 $<$ doi:10.1016/j.intell.2004.06.004>.

Sweeney, Richard T. "Reinventing Library Buildings and Services for the Millennial Generation." Library Administration and Management 19.4 (2005): 165-75.

Tapscott, Don. Grown Up Digital: How the Net Generation is Changing Your World. New York: McGraw-Hill, 2008.

University College London CIBER Group. Information Behaviour of the Researcher of the Future: A CIBER Briefing Paper. JISC and the British Library, 2008. 12 Jan. 2008 $<$ http://www.jisc.ac.uk/media/documents/programmes/reppres/gg final ke ynote 11012008.pdf>. 